\title{
Effect of Acid Treatment on Interfacial and Foam Properties of Soy Proteins
}

\author{
Cecilia Abirached ${ }^{1}$, Claudia Alejandra Medrano ${ }^{1}$, Patrick Moyna ${ }^{1}$, María Cristina Añón ${ }^{2}$ and Luis Alberto \\ Panizzolo ${ }^{1}$ \\ 1. Departamento de Ciencia y Tecnología de los Alimentos, Facultad de Química, Universidad de la República, Montevideo 11800 , \\ Uruguay \\ 2. Food Criotechnology Research and Development Center (CCT-UNLP), School of Exact Sciences, National University of La \\ Plata(UNLP), La Plata 1900, Argentina
}

\begin{abstract}
The goal of the present work was to study the effects of acid treatment on the foaming properties of a soybean protein isolate (SPI) and its fractions, glycinin (11S) and $\beta$-conglycinin (7S). The structural characteristics, interfacial properties, foaming capacity and stability of the treated proteins were studied. Results from surface hydrophobicity and differential scanning calorimetry (DSC) showed that the acid treatment caused the complete denaturation of $11 \mathrm{~S}$ and a partial denaturation of $7 \mathrm{~S}$. This protein unfolding affected their interfacial properties, which led to an improvement in the foaming properties of both protein fractions and isolate. Treated 7S showed the best behavior in the rearrangement process, probably due to its smaller size and its modified structural characteristics. All treated proteins showed stronger interfacial films. The foams of treated proteins were destabilized mostly due to gravitational drainage rather than Ostwald ripening.
\end{abstract}

Key words: Soy proteins, foams, gravitational drainage, Ostwald ripening.

\section{Introduction}

The quality of protein-stabilized foams depends on the composition of their ingredients, the way these ingredients are processed and the properties of the final product. One of the main goals of this research field is to identify the relationship between these factors and the formation, stability and properties (i.e., rheology) of the foam in the final product. Another important goal is to test or predict the foam properties of the final product without actually making the foam. Within production processes, the relevant properties of the proteinaceous liquid should be determined as promptly as possible in order to predict the foam properties. The relevant parameters found in literature are: (1) the liquid's viscosity; (2) the interfacial properties of the adsorbed layers; (3) the disjoining

Corresponding author: Cecilia Abirached, Ph.D., research field: techno-functional properties of proteins. E-mail: abirached@fq.edu.uy. pressure between adsorbed layers in thin liquid films. The viscosity, interfacial tension and dilatational modulus are three parameters that can be easily and rapidly determined for any solution. As a result, some protein foam researchers aim to find a relation between molecular properties and interfacial properties, while others strive to determine the relationship between interfacial properties and foam formation and stability [1].

Foams are colloidal systems containing small air bubbles dispersed in an aqueous phase [2]. The formation of a layer of adsorbed molecules was found to be necessary for the formation and stabilization of foams, since pure liquids do not form stable foams [1]. Three main factors have an impact on foam formation: the number of surfactant molecules in the solution, the adsorption rate of those molecules onto the surface and the dilatational properties of the layer of adsorbed molecules [2]. As often mentioned, faster adsorption 
kinetics (or at least faster decrease of surface tension) relates to a better foam forming capacity of protein solutions [1]. The foaming capacity and the stability of the foam cannot be measured independently because the destabilizing mechanisms and foam formation take place simultaneously [3].

The main mechanisms of foam destabilization are liquid drainage, Ostwald ripening or disproportionation and foam collapse. On one hand, fluid drainage induces a deformation of the film, and as the film gets thinner, the lamella breaks and the foam collapses. On the other hand, Ostwald ripening happens when large bubbles grow at the expense of small bubbles due to gas diffusion through the lamellae [4].

Soybean (Glycine max) is a legume with high protein content. Glycinin and $\beta$-conglycinin are the most abundant storage proteins in soy; they are also named $11 \mathrm{~S}$ and $7 \mathrm{~S}$ globulins, respectively, after their sedimentation coefficients. The $11 \mathrm{~S}$ globulin is composed of 12 subunits: 6 acidic (A) and 6 alkaline (B). The A subunit $\left(\mathrm{MW}_{\mathrm{A}}: 31-38 \mathrm{kDa}\right)$ is linked to the B subunit $\left(\mathrm{MW}_{\mathrm{B}}\right.$ : $\left.18-20 \mathrm{kDa}\right)$ by a disulfide bond. The stability of the quaternary structure of the $11 \mathrm{~S}$ globulin depends on the ionic strength $(\mu)$ and the $\mathrm{pH}$ of the medium [5]. The molecular weight of the $7 \mathrm{~S}$ globulin is $150-200 \mathrm{kDa}$. It is a glycoprotein that contains about $5 \%$ of mannose and $N$-acetylglucosamine and is comprised of three subunits: $\alpha$ (MW: 57-68 kDa), $\alpha^{\prime}$ (MW: 57-72 kDa) and $\beta$ (MW: $42-52 \mathrm{kDa}$ ). This globular trimeric protein is held together by hydrophobic interactions when the ionic strength is more than 0.5 [5].

Soy proteins have been reported to be poor foaming agents, mainly because their compact structure is not prone to absorb and unfold at the film interface, which is necessary for an adequate film formation [6]. Sorgentini et al. [7] studied the effects of thermal and acid treatments on soy protein isolates (SPI) and the $11 \mathrm{~S}$ globulin, showing that the functional properties of these proteins improved after treatment. These proteins are (further) modified by hydrolysis and deamidation reactions that occur under acid conditions and heating [7]. The modification of soy proteins by acid treatment without heating has not been thoroughly studied. Wagner et al. [8] analyzed the changes in structure and functional properties of SPI caused by mild acid treatments at room temperature. Their results showed a selective denaturation of the 11S globulin that increased its surface hydrophobicity. The denaturation and dissociation of the $11 \mathrm{~S}$ globulin within the SPI improved the foaming and foam-stabilization capacity of the isolates. Panizzolo [9] also reported that the foams made with acid-treated SPI were more stable than those made with untreated isolates. Based on this information, determining the way, in which acid treatment affects the functional properties of soy proteins, especially the $7 \mathrm{~S}$ and $11 \mathrm{~S}$ globulins, is very appealing.

The aim of this work was to study the influence of acid treatment on native $11 \mathrm{~S}$ and $7 \mathrm{~S}$ globulins and on SPI, and to compare the foaming and interfacial properties of native and acid-treated samples.

\section{Materials and Methods}

\subsection{SPI and 7S and 11S Fractions}

The native soy protein isolates (SPIn) were obtained by aqueous solubilization of defatted soy flour (Sanbra, S. A., São Paulo, Brazil) under alkaline conditions ( $\mathrm{pH}$ 8.0). The dispersion was centrifugated at $10,000 \times \mathrm{g}$ for $30 \mathrm{~min}$ at $4{ }^{\circ} \mathrm{C}$. The soy proteins were extracted from the supernatant by isoelectric precipitation at $\mathrm{pH}$ 4.5. Then, the precipitate was dispersed in an alkaline solution $(\mathrm{pH}$ 8.0) and freeze-dried for storage [10].

The native $7 \mathrm{~S}$ and $11 \mathrm{~S}$ globulins (7Sn and $11 \mathrm{Sn}$, respectively) were prepared from defatted soy flour according to the procedure proposed by Nagano et al. [11]. The method in Ref. [11] is based on the separation of the $7 \mathrm{~S}$ globulin at $\mathrm{pH} 5.0,4{ }^{\circ} \mathrm{C}$ and a $0.25 \mathrm{M} \mathrm{NaCl}$ bulk concentration. A reducing agent (sodium bisulfite) was used in the isoelectric 
precipitation step in order to obtain a 11S globulin of greater purity and a higher yield of $7 \mathrm{~S}$ globulin.

\subsection{Acid Treatment of SPI and the $7 S$ and $11 S$ Fractions}

In $10 \mathrm{mM}$ sodium phosphate buffer $(\mathrm{pH} 7.0)$, the different native proteins (SPIn, $11 \mathrm{Sn}$ and $7 \mathrm{Sn}$ ) were each dispersed to a concentration of $15 \mathrm{mg} / \mathrm{mL}$, and the mixture was adjusted to $\mathrm{pH} 2.0$ with $6 \mathrm{~N} \mathrm{HCl}$. The samples were freeze-dried after $1 \mathrm{~h}$ of magnetic stirring at room temperature. The acid-treated samples were referred to as SPIt, 7St and 11St.

\subsection{Protein Solubility}

The solubility of SPIn, SPIt, $11 \mathrm{Sn}, 11 \mathrm{St}, 7 \mathrm{Sn}$ and $7 \mathrm{St}$ samples was determined by dispersing these proteins in $10 \mathrm{mM}$ sodium phosphate buffer $(\mathrm{pH} 8.0$ and $\mathrm{pH}$ 2.5) and stirring for $30 \mathrm{~min}$ at room temperature to prepare a $0.1 \% \mathrm{w} / \mathrm{v}$ solution. The dispersions were then centrifuged at $10,000 \times \mathrm{g}$ for 10 min at $4{ }^{\circ} \mathrm{C}$ and the protein content of the supernatant was determined by the Lowry method [12].

\subsection{Surface Hydrophobicity}

Surface hydrophobicity of native and acid-treated SPI, $11 \mathrm{~S}$ and $7 \mathrm{~S}$ samples was evaluated using 8-anilino-1-naphthalenesulfonic acid (ANS) as fluorescent probe according to Hayakawa and Nakai [13]. Spectrofluorometric measurements were taken at pH 7.0 on an Aminco-Bowman Series 2 Luminescence Spectrometer. The fluorescence intensity of the blank and the ANS-protein conjugate were recorded at an excitation wavelength of $363 \mathrm{~nm}$ and an emission wavelength of $475 \mathrm{~nm}$, using $5 \mathrm{~nm}$ emission and excitation slit widths. The surface hydrophobicity $\left(H_{o}\right)$ was obtained using the method described by Kato and Nakai [14].

\subsection{Electrophoresis}

The SPIn, SPIt, $11 \mathrm{Sn}, 11 \mathrm{St}, 7 \mathrm{Sn}$ and $7 \mathrm{St}$ sample solutions were separated by sodium dodecyl sulfate- polyacrylamide gel electrophoresis (SDS-PAGE) in $7 \%-15 \%$ gradient gels under reducing and non-reducing conditions (with or without $\beta$-mercaptoethanol), using a BIO-RAD Mini-PROTEAN $^{\circledR}$ II equipment as described by Petruccelli and Añón [10]. The runs were conducted at a $90 \mathrm{~V}$ constant voltage on two gels $(1.0 \mathrm{~mm}$ of thickness) in a Hoefer SE640 electrophoresis unit. The molecular weight of each protein was estimated by a Pharmacia low molecular weight (LMW) standard consisting of six proteins, whose molecular weights were $14.4,20.1,30.0,45.0,66.0$ and $97.0 \mathrm{kDa}$, respectively. The gels were stained with Coomasie blue R-250 as described by Petruccelli and Añón [10].

The stained gels were scanned and the resulting images were analysed by densitometry using the IMAGE J 1.44 Software. The percent composition of the total storage protein in a given fraction, the purity of the fraction and the composition of a particular subunit of a protein were calculated according to Deak et al. [15].

\subsection{Differential Scanning Calorimetry (DSC)}

The thermal behavior of the SPIn, SPIt, 11Sn, 11St, $7 \mathrm{Sn}$ and $7 \mathrm{St}$ samples was studied. The influence of the neutralization of the treated samples on the thermal properties of the proteins was studied by dispersing each protein in a $10 \mathrm{mM}$ sodium phosphate buffer $(\mathrm{pH}$ 7.0), attaining a protein concentration of $15 \mathrm{mg} / \mathrm{mL}$, then adjusting the dispersions to $2.0 \mathrm{~N} \mathrm{NaOH}$ with $\mathrm{pH}$ 8.0 and finally freeze-drying them. These samples were named: SPIr, $7 \mathrm{Sr}$ and $11 \mathrm{Sr}$, respectively. DSC was performed with a DSC Series Q100 TA instruments device that had been previously calibrated with indium. All determinations were performed using aqueous dispersions of the samples $(20 \% \mathrm{w} / \mathrm{v})$. The samples were scanned at $10{ }^{\circ} \mathrm{C} / \mathrm{min}$ from $20{ }^{\circ} \mathrm{C}$ to $120{ }^{\circ} \mathrm{C}$. A pan containing a sample that had been previously scanned by DSC was used as reference. All the assays were performed at least in triplicate.

Each thermogram was analyzed with the Universal 
Analysis 2000 Software, and the maximal denaturation temperature $(T d)$ and denaturation enthalpy $(\Delta H d)$ were calculated as the area between the thermogram and the baseline. A subscript was added after $T d$ and $\triangle H d$ to indicate the type of sample. Hence, $T d_{n}$ and $\Delta H d_{n}$ correspond to native proteins (SPIn, $11 \mathrm{Sn}$ and $7 \mathrm{Sn}$ ); $T d_{t}$ and $\Delta H d_{t}$ to acid-treated proteins (SPIt, $11 \mathrm{St}$ and $7 \mathrm{St}$ ); and $T d_{r n}$ and $\Delta H d_{r n}$ to neutralized acid-treated proteins (SPIr, $11 \mathrm{Sr}$ and $7 \mathrm{Sr}$ ).

\subsection{Interfacial and Foaming Properties}

Native and treated samples were dispersed at 1 $\mathrm{mg} / \mathrm{mL}$ in $100 \mathrm{mM}$ phosphate buffer $(\mathrm{pH} 8.0)$ as well as in $100 \mathrm{mM}$ phosphate solution ( $\mathrm{pH} 2.5)$ in order to assess the foaming and interfacial properties. The dispersions were named as SPIn-8.0, 11Sn-8.0, 7Sn-8.0, SPIt-8.0, 11St-8.0, 7St-8.0, SPIt-2.5, $11 \mathrm{St}-2.5$ and $7 \mathrm{St}-2.5$, according to the $\mathrm{pH}$ of the solution.

\subsubsection{Determination of Interfacial Properties}

Since the adsorption, rearrangement and unfolding of protein molecules occur simultaneously at the interface, a first-order equation with two exponential terms was used to model the kinetics of surface tension versus time $(\gamma(t))$, as proposed by Panizzolo et al. [16]:

$$
\gamma(t)=A_{a} e^{-k_{a} t}+A_{r} e^{-k_{r} t}+\gamma_{e}
$$

where, $k_{a}$ and $k_{r}$ are first-order rate constants for adsorption and rearrangement processes of proteins at the air-water interface, respectively; $A_{a}, A_{r}$ and $\gamma_{e}$ are the amplitude parameters of surface tension of the different conformational states of the protein at the interface (adsorption, rearrangement and equilibrium). These parameters were estimated by least squares fitting. Determinations were performed at least three times.

Measurements of the equilibrium surface tension at the air-water interface and rheological properties of the films adsorbed on air/water interface of all samples were measured using the pending drop method in a dynamic drop tensiometer (Tracker, IT-Concept, Longessaigne, France) at $20{ }^{\circ} \mathrm{C}$. The protein solution was placed into the tensiometer's cuvette. An air bubble of $5 \mu \mathrm{L}$ was formed with a syringe inside the protein solution. Once the bubble was formed, the changes in surface tension versus time were measured for 7,200 s without applying any variation to the bubble.

The viscoelastic parameters, surface dilational modulus $(E)$ and its elastic and viscous components ( $E_{d}$ and $E_{v}$, respectively) were measured once the tension reached the equilibrium. Sinusoidal variations of the droplet volume (compression-expansion) were applied, using a frequency $(\omega)$ of $200 \mathrm{mHz}$ and deformation amplitude $(\triangle A / A)$ of $10 \%$. Each measurement was performed at least three times.

\subsubsection{Foaming Capacity and Stability Analysis}

The foaming properties of SPIn, SPIt, $11 \mathrm{Sn}, 11 \mathrm{St}$, $7 \mathrm{Sn}$ and $7 \mathrm{St}$ were determined by conductometry, using the method and device developed by Loisel et al. [17]. The foam was formed by sparging air into the protein solution in a column with a G2 fritted glass disk at the bottom. The foaming solutions were prepared in order to evaluate the influence of the $\mathrm{pH}$ of the solution. In all cases, the ionic strength was kept constant at 0.28 by addition of $\mathrm{NaCl}$.

The conductivity of the protein solution as a function of time was measured with a pair of electrodes located at the base of the column. In order to assess the foaming capacity, the maximal volume of retained liquid in the foam $\left(V_{\text {LEmax }}\right)$ and the initial rate of liquid transferred to the foam $\left(v_{0}\right)$ were measured [8].

The destabilization kinetics were studied using the $k_{g}, k_{d}, V_{d}$ and $V_{g}$ parameters, which arise from the kinetic model developed by Panizzolo et al. [18]:

$$
V(t)=\frac{V_{g}^{2} k_{g} t}{V_{g} k_{g} t+1}+\frac{V_{d}^{2} k_{d} t}{V_{d} k_{d} t+1}
$$

where, $V(t)$ is the volume of drained liquid at time $t$; $V_{g}$ is the maximum volume of drained liquid due to 
gravitational drainage; $V_{d}$ is the maximum volume of drained liquid due to Ostwald ripening; $k_{g}$ is the rate constant of the gravitational drainage process; and $k_{d}$ is the rate constant of the Ostwald ripening process.

The contribution of each mechanism to the total volume of drained liquid was assessed in terms of the volume percentage of liquid that is drained due to gravity $\left(V_{g} \%\right)$ and the volume percentage that is drained due to Ostwald ripening $\left(V_{d} \%\right)$. These parameters were calculated as follows:

$$
\begin{aligned}
& V_{g} \%=\frac{V_{g}}{V_{\text {LEmax }}} \times 100 \\
& V_{d} \%=\frac{V_{d}}{V_{\text {LEmax }}} \times 100
\end{aligned}
$$

\subsection{Statistical Analysis}

All the experiments were performed at least in triplicate. The statistical analysis was established by variance analysis and test of minimum significant difference, using the statistical programs Statgraphic Plus 7.0 and Infostat 2011e Version.

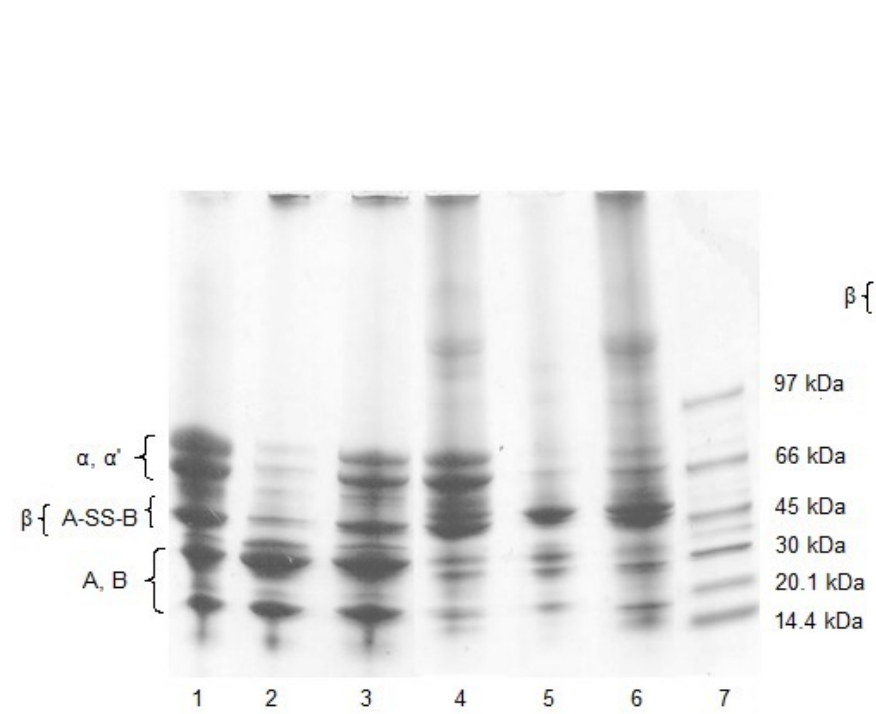

(a)

\section{Results and Discussion}

\subsection{Effect of Acid Treatment on Structural} Characteristics of Proteins

Figs. 1a and 1b show the SDS-PAGE band-pattern of SPIn, $11 \mathrm{Sn}, 7 \mathrm{Sn}, \mathrm{SPIt}, 11 \mathrm{St}$ and $7 \mathrm{St}$ under reducing and non-reducing conditions. In both figures, the characteristic bands of soybean storage globulins, corresponding to the $\alpha, \alpha^{\prime}$ and $\beta$ subunits of $\beta$-conglycinin and the $\mathrm{AB}$ dimers of glycinin, can be seen. The bands corresponding to free $\mathrm{A}$ and $\mathrm{B}$ polypeptides of glycinin are also present in the gel, which is consistent with Wolf's [19] observation that a certain amount of these polypeptides is naturally found free in native soybean proteins' preparations. The 11S protein was comprised of a $50 \mathrm{kDa}$ fraction (A-SS-B dimer) and a 20-30 kDa fraction (subunits A and B) under non-reducing conditions. However, under reducing conditions, the $50 \mathrm{kDa}$ fraction disappeared and only the $20-30 \mathrm{kDa}$ fraction remained.

The 7S protein showed three bands between $60 \mathrm{kDa}$ and $90 \mathrm{kDa}$ under reducing and non-reducing

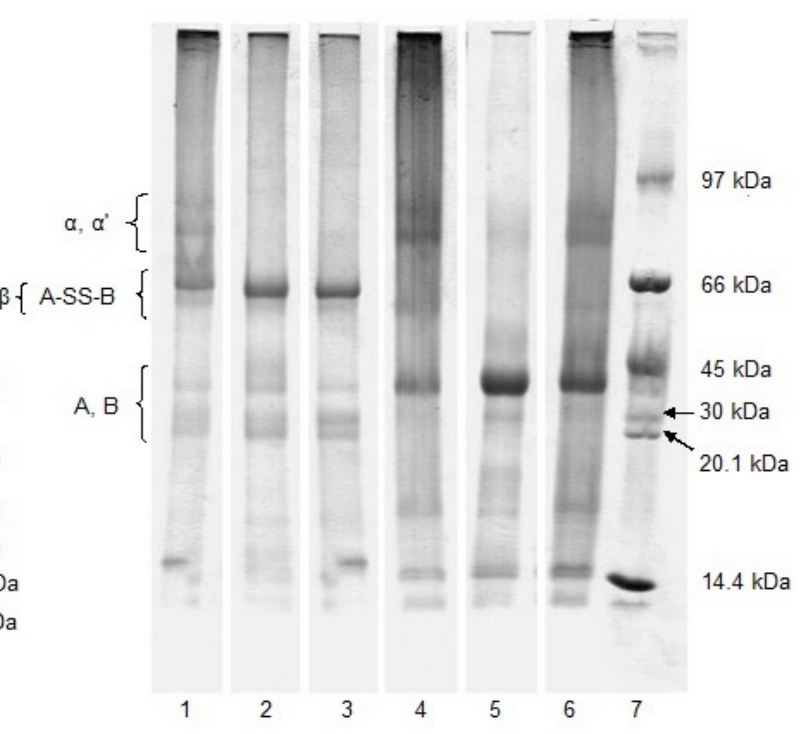

(b)

Fig. 1 SDS-PAGE electrophoresis of native and acid-treated samples as well as a molecularweight (MW) standard. (a): Lanes 1, 2 and 3 correspond to 7Sn, 11Sn and SPIn with $\beta$-mercaptoethanol, respectively; lanes 4, 5 and 6 correspond to 7Sn, $11 \mathrm{Sn}$ and SPIn without $\beta$-mercaptoethanol, respectively; lane 7 corresponds to the MW standard. (b): Lanes 1, 2 and 3 correspond to 7St, 11St and SPIt without $\beta$-mercaptoethanol, respectively; lanes 4,5 and 6 correspond to 7St, 11St and SPIt with $\beta$-mercaptoethanol, respectively; lane 7 corresponds to the MW standard. 
conditions. Although the $7 \mathrm{~S}$ fraction was enriched, it showed bands corresponding to contamination with $11 \mathrm{~S}$ polypeptides (Fig. 1a). The 7Sn sample was analyzed by densitometry so as to determine the amount of $11 \mathrm{~S}$ contamination. The $7 \mathrm{Sn}$ fraction was estimated to be $65 \%$ purity, therefore, the $11 \mathrm{~S}$ polypeptides account for the remaining 35\%. In order to obtain more reliable purity values, the adsorption of each protein to Coomassie blue (staining dye) should have been determined beforehand.

The native samples showed aggregates with molecular weights above $97 \mathrm{kDa}$ (Fig. 1a). In the case of the isolate and the $7 \mathrm{~S}$ fraction, these aggregates must have been at least partially stabilized by disulfides bonds, since the bands disappeared under reducing conditions. The $11 \mathrm{~S}$ fraction may contain larger insoluble aggregates that were not sowed and/or did not enter the gel. Despite having sulfhydryl ( $\mathrm{SH})$ residues, the $7 \mathrm{~S}$ polypeptides seem to be capable of forming aggregates. This observation had already been reported by Petruccelli and Añón [10, 20].

Acid-treated samples showed no bands above 97 kDa (Fig. 1b), presumably because the aggregates detected in native samples had become insoluble during the acid treatment and therefore did not enter the gel. Alternatively, these aggregates may have been dissociated due to the treatment, explaining the absence of these high molecular weight bands. Wagner et al. [8] found that solubility decreased at lower $\mathrm{pH}$, due to higher protein aggregation caused by slightly greater $11 \mathrm{~S}$ denaturation and aggregation rate induced by the increased salt concentration.

The solubility of the SPI and 7S samples decreased after the acid treatment and neutralization (SPIt-8.0 and 7St-8.0 samples) due to the formation of insoluble aggregates (Table 1). These aggregates were detected in the electrophoretic profile. In the native protein, the aggregates' molecular weight was above $97 \mathrm{kDa}$ (Fig. 1a). These aggregates were not detected in the electrophoretic profiles of samples that had been treated with acid and neutralized (Fig. 1b). Probably, these treatments had made them increase their molecular size and made them insoluble.

According to Wagner et al. [8], who had treated isolated soy protein at different $\mathrm{pH}$ values (ranging from 1 to 3.5 ) and subsequently neutralized them in one or two stages, the solubility depends on the neutralization process. In our case, the acid-treated samples were freeze-dried without a previous neutralization and then were dispersed at $\mathrm{pH} 2.5$ or $\mathrm{pH}$ 8.0. Therefore, those samples that were kept at $\mathrm{pH} 2.5$ were never allowed to reach the isoelectric points of the $11 \mathrm{~S}$ and $7 \mathrm{~S}$ fractions $(\mathrm{pH} \quad 6.4$ and 4.8, respectively), which would have favoured the formation of insoluble aggregates [8].

The solubility of $11 \mathrm{Sn}-7.0$ was greater than that of $11 \mathrm{St}-7.0$ and $11 \mathrm{St}-2.5$, probably due to the formation of insoluble aggregates after the acid treatment. These aggregates probably remained insoluble throughout the neutralization process since the $11 \mathrm{~S}$ fraction had already undergone extensive and irreversible denaturation (Table 1).

Table 1 Surface hydrophobicity $\left(H_{o}\right)$ and solubility of the different samples (the solubility is expressed as $g$ of soluble protein/100 g of protein).

\begin{tabular}{llll}
\hline Sample & $H_{o}$ & Solubility at $\mathrm{pH} 8.0$ & Solubility at $\mathrm{pH} 2.5$ \\
\hline $7 \mathrm{Sn}$ & $14 \pm 6^{\mathrm{a}}$ & $88 \pm 1^{\mathrm{c}, \mathrm{d}, \mathrm{e}}$ & ---- \\
$7 \mathrm{St}$ & $16 \pm 7^{\mathrm{a}}$ & $55 \pm 1^{\mathrm{a}}$ & $85 \pm 3^{\mathrm{c}, \mathrm{d}}$ \\
$11 \mathrm{Sn}$ & $17 \pm 2^{\mathrm{a}}$ & $89 \pm 5^{\mathrm{d}, \mathrm{e}}$ & --- \\
$11 \mathrm{St}$ & $30 \pm 3^{\mathrm{b}}$ & $83 \pm 4^{\mathrm{c}}$ & $83 \pm 4^{\mathrm{c}}$ \\
SPIn & $26 \pm 3^{\mathrm{c}}$ & $93 \pm 6^{\mathrm{e}, \mathrm{f}}$ & --- \\
SPIt & $31 \pm 3^{\mathrm{b}}$ & $71 \pm 3^{\mathrm{b}}$ & $95 \pm 4^{\mathrm{f}}$ \\
\hline
\end{tabular}

In each column, those mean values that were not significantly different from each other $(P \leq 0.05)$ are shown with the same superscript letter. ----: The solubility of 7Sn, $11 \mathrm{Sn}$ and SPIn at $\mathrm{pH} 2.5$ was not analysed. 


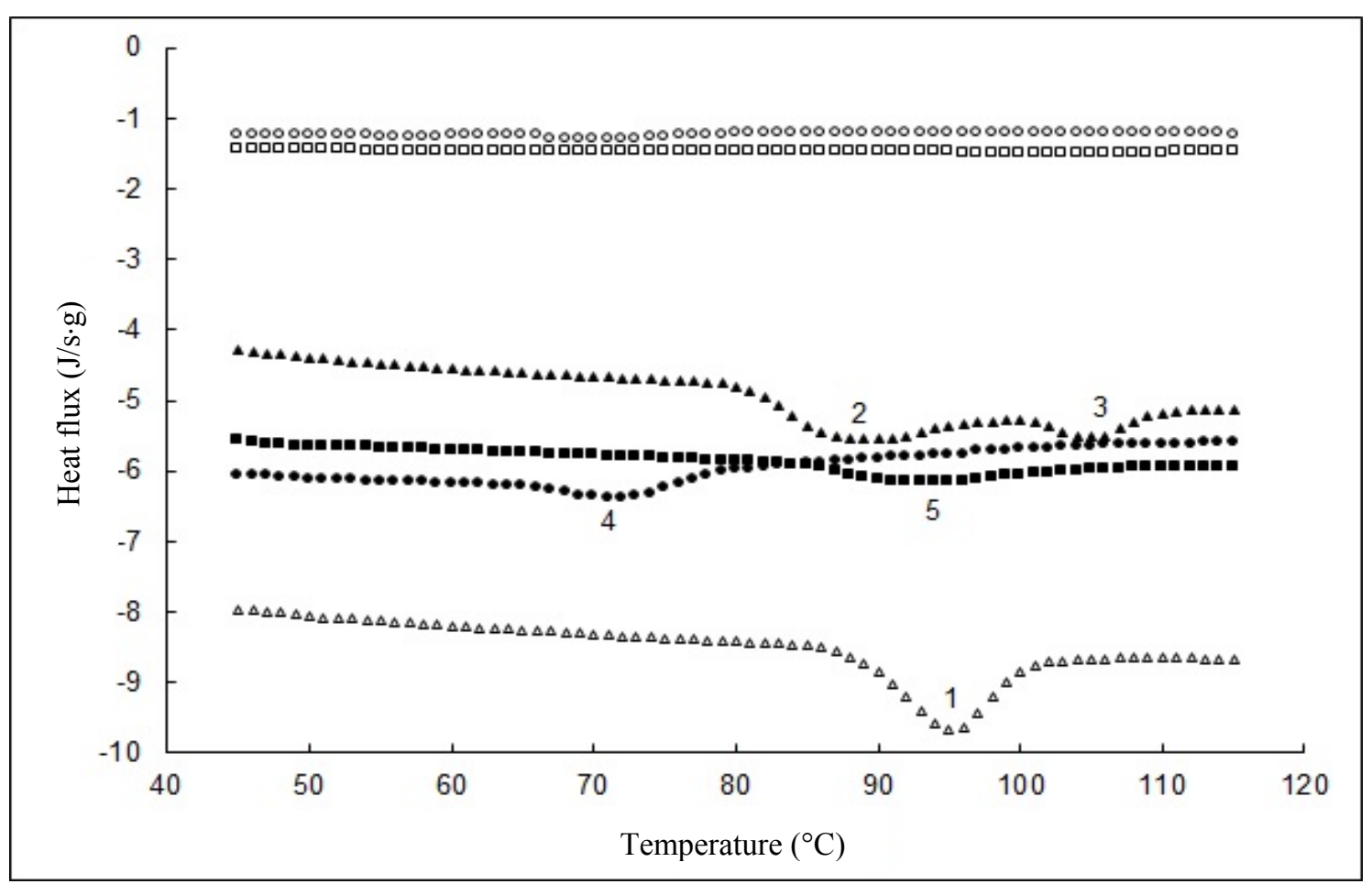

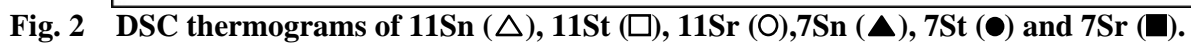

The $\Delta H d$ of the peaks are: $1: 18 \pm 2 \mathrm{~J} / \mathrm{g}, 2: 9 \pm 1 \mathrm{~J} / \mathrm{g}, 3: 2 \pm 1 \mathrm{~J} / \mathrm{g}, 4: 3.3 \pm 0.4 \mathrm{~J} / \mathrm{g}$ and $5: 6 \pm 2 \mathrm{~J} / \mathrm{g}$.

Fig. 2 shows the thermograms of acid-treated and untreated 11S globulin. The thermogram of the native sample (11Sn) showed an endothermic peak corresponding to the $11 \mathrm{~S}$ globulin, while the thermogram of the treated sample (11St) showed no peaks at all. This indicates that the acid treatment led to a complete denaturation of the $11 \mathrm{~S}$ globulin. Furthermore, the absence of peaks in the thermogram of the neutralized sample $(11 \mathrm{Sr})$ demonstrates that this denaturation was also irreversible (Fig. 2).

The thermograms of the 7Sn sample (Fig. 2) showed two endothermic peaks: one with a lower $T d_{n}$ value, corresponding to the $7 \mathrm{~S}$ globulin; and another peak corresponding to the $11 \mathrm{~S}$ globulin, which had already been shown to be a contaminant in the SDS-PAGE analysis [21-24]. In the thermogram of the 7St sample, the endothermic peak that was attributed to the $11 \mathrm{~S}$ globulin disappeared, whereas the other endotherm showed lower $T d_{t}$ and $\Delta H d_{t}$ values than its native counterpart (the $7 \mathrm{Sn}$ sample). This behavior may be ascribed to the dissociation of the $7 \mathrm{~S}$ trimer and the denaturation of the $11 \mathrm{~S}$ globulin.
The thermogram of the $7 \mathrm{Sr}$ sample only showed the endothermic peak corresponding to $7 \mathrm{~S}$ globulin, whose denaturation temperature $\left(T d_{r}\right)$ was greater than that of the treated and native samples $\left(T d_{t}\right.$ and $\left.T d_{n}\right)$. However, the denaturation enthalpy of the 7Sr sample was between the denaturation enthalpies of the corresponding treated and native samples $\left(\Delta H d_{t}<\right.$ $\left.\Delta H d_{r}<\Delta H d_{n}\right)$. According to Puppo [25], this phenomenon may be explained by the formation of a new structure that is completely different from the native one or to an incomplete recovery of the native structure. These results suggest that $7 \mathrm{~S}$ globulin is more resistant to acid-induced denaturation than the $11 \mathrm{~S}$ globulin.

The thermograms of SPIn, SPIt and SPIr had similar profiles to $7 \mathrm{Sn}, 7 \mathrm{St}$ and $7 \mathrm{Sr}$ thermograms, and therefore are not shown here (see Abirached et al. [26] for the SPI thermograms). The SPIn thermogram showed two endothermic peaks characteristic of the thermal denaturation of soybean $7 \mathrm{~S}$ and $11 \mathrm{~S}$ globulins [21-24].

The surface hydrophobicity values $\left(H_{o}\right)$ of the 
different samples are shown in Table 1 . The $H_{o}$ values of the $7 \mathrm{Sn}$ and $7 \mathrm{St}$ samples showed no significant differences $(P \leq 0.05)$ despite the denaturation and dissociation caused by the acid treatment. On the other hand, $11 \mathrm{St}$ and SPIt samples showed higher $H_{o}$ values than their corresponding native samples (11Sn and SPIn), as previously reported by Wagner et al. [8]. The increase of $H_{o}$ found in the acid-treated samples could be a result of conformational changes produced by the exposure to the strongly acidic media.

\subsection{Interfacial Properties}

Table 2 shows the results of the interfacial parameters of the tested solutions. The surface tension of room temperature water at equilibrium $\left(\gamma_{e}\right)$ was 72 $\mathrm{mN} / \mathrm{m}$ and decreased due to the presence of protein. The main difference between the interfacial properties of all acid-treated samples was the change rate of the surface tension. Moreover, no significant difference between the surface tension at equilibrium of SPI, 7S and $11 \mathrm{~S}$ was found $(P \leq 0.05)$. In addition, there were no significant differences between the rearrangement rate constants $\left(k_{r}\right)$ of SPIn and SPIt and between the $k_{r}$ constants of $11 \mathrm{Sn}$ and $11 \mathrm{St}$. The reason behind this could be that the native samples reached the interface with a similar conformational state as that of the acid-treated samples. A different result was observed with the $7 \mathrm{~S}$ samples (Table 2): 7St-2.5 showed a lower $k_{r}$ value than $7 \mathrm{Sn}-8.0$ and $7 \mathrm{St}-8.0$ (7St-8.0 showed the highest $k_{r}$ value of the three). This behavior may be attributed to the different conformational states of $7 \mathrm{~S}$ under the different conditions, as shown by DSC results.

The $7 \mathrm{~S}$ and $11 \mathrm{~S}$ fraction showed a significant $(P \leq$ $0.05)$ increase in the adsorption rate constants $\left(k_{a}\right)$ after the acid treatment (Table 2). The increase shown by the $11 \mathrm{~S}$ globulin probably results from the increase of its surface hydrophobicity, since the amount of hydrophobic patches on the surface of a protein molecule has a direct correlation with its penetration into the interface during the adsorption process. Moreover, the denatured 11S would mostly be as AB dimers, which, according to Martin et al. [27], has a faster adsorption rate at the interface because of its greater flexibility that arises from the increased electrostatic repulsion inside the molecule. The different behaviors of $7 \mathrm{St}-2.5$ and $7 \mathrm{St}-8.0$ during the adsorption process may be attributed to the different structures adopted by $7 \mathrm{St}$ in those conditions. The structure of $7 \mathrm{St}-2.5$ would cause less hindrance during adsorption, whereas the structure of $7 \mathrm{St}-8.0$ would cause a major steric impediment in that process. The $k_{a}$ values of native and acid-treated SPI samples were not significantly different from each other $(P \leq 0.05)$. The behavior of the $7 \mathrm{~S}$ and $11 \mathrm{~S}$ globulins was not reflected in SPI, probably because these proteins

Table 2 Adsorption rate constant $\left(k_{a}\right)$, rearrangement rate constant $\left(k_{r}\right)$, equilibrium surface tension $\left(\gamma_{\mathrm{e}}\right)$, surface dilational modulus $(E)$, its elastic $\left(E_{d}\right)$ and viscous $\left(E_{v}\right)$ components and the loss angle tangent $(\operatorname{tg} \varphi)$ of different samples (sample concentration: $1 \mathrm{mg} / \mathrm{mL}$ in $10 \mathrm{mM}$ sodium phosphate solution, $\mathrm{pH} 8.0$ and 2.5).

\begin{tabular}{llllllll}
\hline Samples & $\begin{array}{l}k_{a} \times 10 \\
\left(\mathrm{~s}^{-1}\right)\end{array}$ & $\begin{array}{l}k_{r} \times 10^{2} \\
\left(\mathrm{~s}^{-1}\right)\end{array}$ & $\begin{array}{l}\gamma_{\mathrm{e}} \\
(\mathrm{mN} / \mathrm{m})\end{array}$ & $\begin{array}{l}E \\
(\mathrm{mN} / \mathrm{m})\end{array}$ & $\begin{array}{l}E_{d} \\
(\mathrm{mN} / \mathrm{m})\end{array}$ & $\begin{array}{l}E_{v} \\
(\mathrm{mN} / \mathrm{m})\end{array}$ & $\operatorname{tg} \varphi$ \\
\hline SPIn-8.0 & $0.9 \pm 0.1^{\mathrm{b}, \mathrm{c}}$ & $0.61 \pm 0.08^{\mathrm{b}}$ & $42 \pm 4^{\mathrm{b}}$ & $27 \pm 3^{\mathrm{b}, \mathrm{c}}$ & $27 \pm 4^{\mathrm{b}}$ & $4 \pm 3^{\mathrm{a}, \mathrm{b}}$ & $0.2 \pm 0.2^{\mathrm{a}}$ \\
SPIt-8.0 & $0.9 \pm 0.1^{\mathrm{a}, \mathrm{b}, \mathrm{c}}$ & $0.67 \pm 0.06^{\mathrm{b}, \mathrm{c}}$ & $41 \pm 3^{\mathrm{b}}$ & $24 \pm 1^{\mathrm{a}, \mathrm{b}}$ & $22.6 \pm 0.8^{\mathrm{a}}$ & $7.4 \pm 0.8^{\mathrm{c}}$ & $0.33 \pm 0.03^{\mathrm{b}}$ \\
SPIt-2.5 & $0.81 \pm 0.07^{\mathrm{a}, \mathrm{b}}$ & $0.60 \pm 0.08^{\mathrm{a}, \mathrm{b}}$ & $39.7 \pm 0.6^{\mathrm{a}, \mathrm{b}}$ & $41 \pm 1^{\mathrm{e}}$ & $41 \pm 1^{\mathrm{d}}$ & $4.3 \pm 0.4^{\mathrm{a}, \mathrm{b}}$ & $0.11 \pm 0.01^{\mathrm{a}}$ \\
$11 \mathrm{Sn}-8.0$ & $0.69 \pm 0.05^{\mathrm{a}}$ & $0.7 \pm 0.2^{\mathrm{b}, \mathrm{c}}$ & $40.1 \pm 0.5^{\mathrm{a}, \mathrm{b}}$ & $21 \pm 2^{\mathrm{c}, \mathrm{d}}$ & $21 \pm 2^{\mathrm{b}, \mathrm{c}}$ & $2.2 \pm 0.3^{\mathrm{a}}$ & $0.2 \pm 0.2^{\mathrm{a}}$ \\
$11 \mathrm{St}-8.0$ & $1.0 \pm 0.1^{\mathrm{b}, \mathrm{c}}$ & $0.76 \pm 0.01^{\mathrm{c}}$ & $41 \pm 3^{\mathrm{b}}$ & $33 \pm 1^{\mathrm{d}}$ & $32 \pm 1^{\mathrm{c}}$ & $6.7 \pm 0.2^{\mathrm{b}, \mathrm{c}}$ & $0.21 \pm 0.02^{\mathrm{a}}$ \\
$11 \mathrm{St}-2.5$ & $1.1 \pm 0.5^{\mathrm{c}}$ & $0.67 \pm 0.08^{\mathrm{b}, \mathrm{c}}$ & $40.3 \pm 0.3^{\mathrm{a}, \mathrm{b}}$ & $50 \pm 3^{\mathrm{f}}$ & $50 \pm 4^{\mathrm{e}}$ & $5.2 \pm 0.8^{\mathrm{a}, \mathrm{b}, \mathrm{c}}$ & $0.10 \pm 0.02^{\mathrm{a}}$ \\
7 Sn-8.0 & $0.9 \pm 0.2^{\mathrm{a}, \mathrm{b}, \mathrm{c}}$ & $0.61 \pm 0.06^{\mathrm{b}}$ & $40 \pm 2^{\mathrm{a}, \mathrm{b}}$ & $21 \pm 1^{\mathrm{a}}$ & $21 \pm 2^{\mathrm{a}}$ & $3 \pm 2^{\mathrm{a}}$ & $0.17 \pm 0.09^{\mathrm{a}}$ \\
7 St-8.0 & $1.5 \pm 0.1^{\mathrm{d}}$ & $0.9 \pm 0.1^{\mathrm{d}}$ & $39 \pm 2^{\mathrm{a}, \mathrm{b}}$ & $32 \pm 3^{\mathrm{d}}$ & $31 \pm 3^{\mathrm{c}}$ & $6 \pm 1^{\mathrm{a}, \mathrm{b}, \mathrm{c}}$ & $0.19 \pm 0.03^{\mathrm{a}}$ \\
7 St-2.5 & $1.9 \pm 0.2^{\mathrm{e}}$ & $0.47 \pm 0.04^{\mathrm{a}}$ & $40 \pm 2^{\mathrm{a}}$ & $41 \pm 2^{\mathrm{e}}$ & $41 \pm 9^{\mathrm{d}}$ & $3 \pm 1^{\mathrm{a}, \mathrm{b}, \mathrm{c}}$ & $0.13 \pm 0.01^{\mathrm{a}}$ \\
\hline
\end{tabular}

In each column, those mean values that were not significantly different from each other $(P \leq 0.05)$ are shown with the same superscript letter. 
Table 3 Foam capacity parameters ( $V_{\text {LEmax }}$ and $\left.v_{0}\right)$, foam stability parameters $\left(k_{g}\right.$ and $\left.k_{r}\right)$, and contribution of gravitational drainage $\left(V_{g} \%\right)$ and disproportionation $\left(V_{d} \%\right)$ mechanisms to the overall volume of drained liquid, for all samples under different conditions.

\begin{tabular}{lllllll}
\hline Samples & $V_{L E \max }(\mathrm{mL})$ & $v_{0}(\mathrm{~mL} / \mathrm{s})$ & $k_{g} \times 10^{3}(\mathrm{~mL} / \mathrm{s})$ & $k_{d} \times 10^{4}(\mathrm{~mL} / \mathrm{s})$ & $V_{g}(\%)$ & $V_{d}(\%)$ \\
\hline SPIn-8.0 & $3.5 \pm 0.3^{\mathrm{a}}$ & $0.15 \pm 0.01^{\mathrm{a}}$ & $13 \pm 1^{\mathrm{c}}$ & $13 \pm 5^{\mathrm{c}}$ & $88 \pm 5^{\mathrm{d}}$ & $12 \pm 5^{\mathrm{a}}$ \\
SPIt-8.0 & $7.0 \pm 0.3^{\mathrm{d}}$ & $0.30 \pm 0.03^{\mathrm{d}, \mathrm{e}}$ & $3.3 \pm 0.5^{\mathrm{a}}$ & $8 \pm 3^{\mathrm{b}, \mathrm{c}}$ & $92 \pm 8^{\mathrm{d}}$ & $8 \pm 8^{\mathrm{a}}$ \\
SPIt-2.5 & $8.4 \pm 0.2^{\mathrm{e}, \mathrm{f}}$ & $0.32 \pm 0.04^{\mathrm{e}, \mathrm{f}}$ & $3.4 \pm 0.4^{\mathrm{a}}$ & $5 \pm 1^{\mathrm{a}, \mathrm{b}}$ & $79 \pm 3^{\mathrm{c}}$ & $21 \pm 3^{\mathrm{b}}$ \\
$11 \mathrm{Sn}-8.0$ & $4.3 \pm 0.3^{\mathrm{b}}$ & $0.22 \pm 0.03^{\mathrm{b}}$ & $17 \pm 3^{\mathrm{d}}$ & $3 \pm 1^{\mathrm{a}, \mathrm{b}}$ & $63 \pm 5^{\mathrm{a}}$ & $37 \pm 5^{\mathrm{d}}$ \\
$11 \mathrm{St}-8.0$ & $8.1 \pm 0.4^{\mathrm{c}}$ & $0.32 \pm 0.07^{\mathrm{e}, \mathrm{f}}$ & $3.3 \pm 0.4^{\mathrm{a}}$ & $4 \pm 2^{\mathrm{a}, \mathrm{b}}$ & $71.1 \pm 0.3^{\mathrm{b}, \mathrm{c}}$ & $28.9 \pm 0.3^{\mathrm{b}, \mathrm{c}}$ \\
$11 \mathrm{St}-2.5$ & $8.61 \pm 0.01^{\mathrm{f}}$ & $0.36 \pm 0.02^{\mathrm{f}}$ & $3.5 \pm 0.4^{\mathrm{a}}$ & $5.3 \pm 0.8^{\mathrm{a}, \mathrm{b}}$ & $73 \pm 3^{\mathrm{b}, \mathrm{c}}$ & $27 \pm 3^{\mathrm{b}, \mathrm{c}}$ \\
7 Sn-8.0 & $6.3 \pm 0.4^{\mathrm{c}}$ & $0.30 \pm 0.02^{\mathrm{b}, \mathrm{c}}$ & $5.6 \pm 0.4^{\mathrm{b}}$ & $1 \pm 2^{\mathrm{a}}$ & $70 \pm 6^{\mathrm{a}, \mathrm{b}}$ & $30 \pm 6^{\mathrm{c}, \mathrm{d}}$ \\
7 St-8.0 & $8.3 \pm 0.3^{\mathrm{e}}$ & $0.360 \pm 0.009^{\mathrm{c}, \mathrm{d}}$ & $2.7 \pm 0.4^{\mathrm{a}}$ & $9 \pm 3^{\mathrm{b}, \mathrm{c}}$ & $79 \pm 2^{\mathrm{c}}$ & $21 \pm 2^{\mathrm{b}}$ \\
7 St-2.5 & $8.4 \pm 0.1^{\mathrm{e}, \mathrm{f}}$ & $0.36 \pm 0.02^{\mathrm{d}, \mathrm{e}}$ & $3.0 \pm 0.1^{\mathrm{a}}$ & $12 \pm 8^{\mathrm{c}}$ & $79 \pm 2^{\mathrm{c}}$ & $21 \pm 2^{\mathrm{b}}$ \\
\hline
\end{tabular}

In each column, those mean values that were not significantly different from each other $(P \leq 0.05)$ are shown with the same superscript letter.

compete for adsorption at the interface.

Table 2 shows the interfacial rheological parameters of the samples. The elastic component value of $11 \mathrm{St}-2.5$ was almost two times greater than that of $11 \mathrm{Sn}-8.0$ and $11 \mathrm{St}-8.0$. Consequently, the film has greater resistance, which minimizes external disturbances and prevents its rupture [28]. The $11 \mathrm{St}-8.0$ and $11 \mathrm{St}-2.5$ viscous modulus were significantly higher than that of $11 \mathrm{Sn}$.

The film that was formed by the 7S fraction showed a similar behavior as that of the $11 \mathrm{~S}$ film. This behavior may be a consequence of the $11 \mathrm{~S}$ contaminants present in the $7 \mathrm{~S}$ fraction.

Regarding the dilational modulus $(E)$, no significant differences between SPIn and SPIt-8.0 values were detected. Both values were lower than that of SPIt-2.5, suggesting that in the latter case a more resistant film was formed (Table 2). The dilational elastic and viscous components $\left(E_{d}\right.$ and $\left.E_{v}\right)$ of SPIn and SPIt-8.0 showed significant differences between these fractions. Moreover, the viscous dilational modulus $\left(E_{v}\right)$ of SPIt-8.0 was higher than that of SPIn-8.0. Considering that a higher surface viscosity of the film prevents mechanical distortions, which could lead to its rupture [29], this result indicates that the films formed by SPIt-8.0 are probably more resistant.

As in the case of $11 \mathrm{~S}$ fraction, the elastic component $\left(E_{d}\right)$ of the SPIt-2.5 was almost two times greater than that of SPIn-8.0 and SPIt-8.0. However, the $E_{v}$ of SPIt- 8.0 was higher than that of SPIn- 8.0 and SPIt-2.5.

For all the tested samples, the value of the loss angle tangent $(\operatorname{tg} \varphi)$, defined as $\operatorname{tg} \varphi=E_{v} / E_{d}$, ranged from 0.10 to 0.33 , suggesting that the interface behavior at the interface of the films made with the native and treated proteins is predominantly elastic (Table 2). This behavior is governed by the experimental test frequency, which, in this case, was $200 \mathrm{mHz}[30,31]$.

\subsection{Foaming Capacity}

According to the $v_{0}$ and $V_{\text {LEmax }}$ parameters, the foaming capacity of the isolate and the fractions improved after the acid treatment (Table 3). At $\mathrm{pH} 8.0$, the native $7 \mathrm{~S}$ fraction $(7 \mathrm{Sn}-8.0)$ showed a better foaming capacity than the native $11 \mathrm{~S}$ fraction (11Sn-8.0). The fraction with the greatest improvement in foaming capacity after the acid treatment was $11 \mathrm{~S}$.

The $v_{0}$ and $V_{\text {LEmax }}$ values of SPIt-2.5, 11St-2.5 and 7St-2.5, were not significantly different $(P \leq 0.05)$ from those of SPIt-8.0, 11 St- 8.0 and $7 \mathrm{St}-8.0$, except for the $V_{L E \max }$ value of SPIt-2.5 and SPIt-8.0.

The $V_{\text {LEmax }}$ and $v_{0}$ values of $11 \mathrm{St}-8.0$ and $11 \mathrm{St}-2.5$ were higher than those of $11 \mathrm{Sn}-8.0$. This result is consistent with the improved interfacial properties of 
acid-treated 11S, which showed a more pronounced decrease of surface tension due to adsorption of proteins at the interface ( $k_{r}$ values, Table 2$)$ and better film properties ( $E_{d}$ and $E_{v}$ values, Table 2).

$V_{L E \max }$ values of $7 \mathrm{St}-8.0$ and $7 \mathrm{~S}-2.5$ were higher than that of $7 \mathrm{Sn}-8.0$. However, there was no significant difference between the $v_{0}$ values of $7 \mathrm{St}$ and 7Sn. In this case, the better adsorption and rearrangement at the interface of the treated $7 \mathrm{~S}$ would in turn reflect in $V_{\text {LEmax }}$ values, but not in $v_{0}$.

SPIt-8.0 and SPIt-2.5 exhibited higher values of $V_{\text {LEmax }}$ and $v_{0}$ than SPIn-8.0. Since SPIn-8.0, SPIt-8.0 and SPIt-2.5 showed similar $k_{a}$ and $k_{r}$ values (Table 2), no relationship between the variation of foaming capacity parameters $\left(V_{\text {LEmax }}\right.$ and $\left.v_{0}\right)$ and the kinetics of surface tension variation were found. As previously discussed, the interfacial films formed by SPIt- 8.0 and by SPIt- 2.5 were more resistant to rupture. The fact that SPIt-8.0 showed a higher $E_{v}$ and SPIt-2.5 showed a higher $E_{d}$ than SPIn-8.0 would explain the improvement of $v_{0}$ and $V_{\text {LEmax }}$ of SPIt-8.0 and SPIt-2.5.

\subsection{Foam Stability}

All native and treated proteins showed that gravitational drainage values $\left(k_{g}\right)$ were greater than Ostwald ripening $\left(k_{d}\right)$ by an order of magnitude (Table 3). This behavior agrees with results obtained by $\mathrm{Yu}$ and Damoradan [32], who proposed that the gravity drainage process predominates during the early stages of foam destabilization, whereas liquid drainage caused by the Ostwald ripening becomes more important in the final stages.

Overall, the foams made with the acid-treated samples were more stable (Table 3). At pH 8.0, foams prepared with $11 \mathrm{Sn}$ were unstable due to Ostwald ripening and gravity drainage. However, at $\mathrm{pH} 8.0$, the most stable foams were obtained with the treated isolate and treated fractions, whose stability constants showed no significant differences ( $P \leq 0.05$, Table 3$)$.

The foams that were made with SPI and $11 \mathrm{~S}$ had an improved resistance to gravitational drainage and Ostwald ripening after acid treatment. There was no significant difference between the foams that were made with treated samples and dispersed at $\mathrm{pH} 8.0$ and those that were dispersed at $\mathrm{pH} 2.5$. The foams made with $7 \mathrm{~S}$ showed an improved stability to gravitational drainage after the acid treatment, yet their stability to Ostwald ripening decreased.

Once located and properly oriented at the interface, proteins should be able to interact with neighbouring molecules to create a strong viscoelastic film capable of withstanding the mechanical and thermal distortions, thus providing stability to the foam. The formation of a protein network with gel characteristics is a balance between protein-protein and protein-water interactions. Most studies point out that denaturation and unfolding of the proteins are necessary to achieve an ordered protein-protein interaction. The more ordered this interaction is, the more homogeneous, elastic and stable towards water loss the structure will be. Such a structure would have more endurance to the gravitational and capillary drain process (Plateau edge effect), which probably plays the greater role in the initial phase of the foam's destabilization mechanism.

Since SPIt and 11St proteins have an unfolded conformation at the interface, they were expected to provide gel-like characteristics to the protein film, resulting in a greater stability of the foam. On the contrary, SPIn and $11 \mathrm{Sn}$ proteins are not likely to be unfolded at the interface and therefore cannot confer the same gel-like characteristics to the interfacial film as the SPIt and 11St proteins.

The conformation of $7 \mathrm{St}$ probably promotes the formation of a gel-like film at the interface to a greater extent than $7 \mathrm{Sn}$, due to its lower $k_{g}$. Furthermore, water retention at the interfacial film is favored by $\beta$-conglycinin's glycosylation, which could explain why the 7Sn foam is more stable than the 11Sn foam.

The stability of the film was improved by the acid treatment, which is consistent with the afore mentioned increase of $E_{d}$ and $E_{v}$, indicating that more 
resistant interfacial films were produced.

The bubble size has an impact on the amount of drained liquid; the larger the bubble's radius is, the lesser the amount of drained liquid is. The average size of the bubbles was not determined quantitatively, but visual observations were made. The bubble size of the foams made with SPIn, 7Sn and 11Sn was bigger than that of foams made with SPIt, $11 \mathrm{St}$ and $7 \mathrm{St}$ at $\mathrm{pH}$ 8.0 and 2.5. Foams that were made with the native proteins had greater density and smaller bubble size at the beginning of foaming than at the end of bubbling. In contrast, the foams made with the acid-treated proteins (both at $\mathrm{pH} 8.0$ and $\mathrm{pH} 2.5$ ) showed the same foam aspect and bubble size throughout the sparging process. This indicates that destabilization processes also occur during foaming and are most noticeable when foam is made from native proteins (without acid treatment).

Foams that were made with acid-treated proteins had a lower drainage rate despite having a smaller bubble size. This shows that the characteristics and performances of these proteins at the interfacial film are capable of overcoming greater drainage forces. Consequently, acid-treated proteins have more stabilizing capacity than native proteins.

SPIn foams showed less resistance to Ostwald ripening, as is deduced from the $k_{d}$ value, which was greater than those of SPIt foams in an order of magnitude (Table 3). Considering that Ostwald ripening can be inhibited or delayed by the presence of a thick interfacial film that reduces gas permeability [33], this finding is consistent with the $E_{v}$ and $E_{d}$ value increase (Table 2).

7Sn foams showed a higher stability against Ostwald ripening than $7 \mathrm{St}-8.0$ and $7 \mathrm{St}-2.5$ foams, as is deduced from the $k_{d}$ value (Tables 3 ). This observation does not agree with the increase of $E_{d}$ and $E_{v}$ (Table 2). Nevertheless, Ostwald ripening also has an inverse correlation with the bubble size. $7 \mathrm{Sn}$ foams had larger bubbles; this may be the predominant factor responsible for the resistance to Ostwald ripening.
The $k_{d}$ values of foams made with $11 \mathrm{Sn}-8.0$, $11 \mathrm{St}-8.0$ and $11 \mathrm{St}-2.5$ were not significantly different $(P \leq 0.05)$ (Table 3$)$. In this case, the presence of an interfacial film that is resistant to inter-bubble gas diffusion, as can be deduced from the increase of $E_{d}$ and $E_{v}$ values (Table 2), counteracted the effect of the bubble size.

Table 3 shows the values of $V_{g} \%$ and $V_{d} \%$. In all cases, the drained volume due to gravitational drainage $\left(V_{g} \%\right)$ was significantly higher (over $60 \%$ ) than the drained volume due to Ostwald ripening $\left(V_{d} \%\right) .11 \mathrm{St}$ and $7 \mathrm{St}$ foams showed a greater proportion of gravitational drainage than native ones, probably because they had a more resistant film, as was inferred from their $E_{v}$ and $E_{d}$ values.

The increase of the elastic component $\left(E_{d}\right)$ of SPIt-2.5 with respect to that of SPIt-8.0 and SPIn-8.0 was reflected in the values of $V_{g} \%$ and $V_{d} \%$, but not in $k_{g}$ and $k_{d}$. SPIt-8.0 showed a lower value of $V_{d} \%$ than SPIt-2.5, because SPIt- 8.0 showed a higher dilational viscosity $\left(E_{v}\right)$ that prevents the film's rupture. This higher value of the viscous component of SPIt-8.0 explains the lower rate of Ostwald ripening (lower $\left.V_{d} \%\right)$.

\section{Conclusions}

Foam properties correspond to the physico-chemical and structural changes caused by the acid treatment. The complete denaturation of $11 \mathrm{~S}$ and the partial denaturation of 7S caused by acid treatment, affected the behavior of these proteins in the air-water interface and consequently their foaming properties. The interfacial properties of these proteins were related to their ability to form and stabilize foams by determining the kinetics of the protein adsorption and rearrangement in the air-water interface and the rheological parameters of the interfacial films. The rearrangement process of SPI and 11S globulins did not differ significantly from each other, as shown by the corresponding kinetic constant values $\left(k_{r}\right)$. However, this process was different for $7 \mathrm{~S}$, probably 
due to its lower molecular mass and the different conformational states shown under the different conditions. The interfacial rheology results indicated that the interfacial films' resistance was improved by the treatment, as shown by the increase of the $E, E_{d}$ and $E_{v}$ parameters. According to the $V_{L E \max }$ and $v_{0}$ values, the foaming capacity of the isolate and of the fractions was improved by the acid treatment. It has also been able to discriminate the contribution of Ostwald ripening and gravitational drainage to the destabilization process. Overall, the treated isolate and fractions were the most stable samples towards gravitational drainage (lower $k_{g}$ ). SPIt foams were more stable towards Ostwald ripening than SPIn foams, presumably because they had a thicker interfacial film that prevented gas diffusion. This result is consistent with the increase in $E_{d}$ and $E_{v}$ values. $7 \mathrm{Sn}$ foams were more stable towards Ostwald ripening than $7 \mathrm{St}-8.0$ and $7 \mathrm{St}-2.5$ foams, probably due to the larger bubble size in the 7Sn foams. In all cases, the predominant destabilization mechanism was the gravitational drainage. In conclusion, the foaming properties of the soybean protein isolate and the $7 \mathrm{~S}$ and $11 \mathrm{~S}$ fractions improved after acid treatment.

\section{Acknowledgments}

The authors would like to thank Laboratorio Tecnológico del Uruguay (Uruguayan Technical Laboratory, LATU) and the School of Chemistry of the University of the Republic (UDELAR) for the Ph.D. scholarship granted to Cecilia Abirached, as well as Plan de Desarrollo Tecnológico (Technological Development Plan, PDT) of the Uruguayan Ministry of Education and Culture (S/C/O/66/12 Project and S/C/BE/55/10 scholarship) and Plan de Desarrollo de las Ciencias Básicas (Development Plan for Basic Sciences, PEDECIBA) for their financial support. The authors wish to thank Luis Mussio, Álvaro Gancharov, Eduardo Aguilar and Heinkel Bentos-Pereira (Instruments Unit, School of Chemistry) and Daniel Acosta y Lara (Glassware
Repair Unit, School of Chemistry) for their help in the design and construction of the apparatus that was used to evaluate foaming properties.

\section{References}

[1] Wierenga, P. A., and Gruppen, H. 2010. "New Views on Foams from Protein Solutions." Curr. Opin. Colloid Interface Sci. 15 (5): 365-73.

[2] Carrera-Sánchez, C., and Rodríguez-Patino, J. M. 2005. "Interfacial, Foaming and Emulsifying Characteristics of Sodium Caseinate as Influenced by Protein Concentration in Solution." Food Hydrocolloids 19 (3): 407-16.

[3] Langevin, D. 2000. "Influence on Interfacial Rheology on Foam and Emulsion Properties." Adv. Colloid Interface Sci. 88 (1-2): 209-22.

[4] Wagner, J. R. 2000. "Surface Properties." In Functional and Structural Characterization of Proteins, edited by Bartholomai, W., and Pilosof, A. M. R. Buenos Aires, Argentina: EUDEBA, 41-74. (in Spanish)

[5] Cheftel, J. C., Cuq, J. L., and Lorient, D. 1989. Food Proteins: Biochemistry, Functional Properties, Nutritional Value, Chemical Modifications. Zaragoza, Spain: Acribia, 257-75. (in Spanish)

[6] German, J. B., O’Neill, T. E., and Kinsella, J. E. 1985. "Film Forming and Foaming Behavior of Food Proteins." J. Am. Oil Chem. Soc. 62 (9): 1358-66.

[7] Sorgentini, D. A., Wagner, J. R., and Añón, M. C. 1995. "Effects of Thermal Treatment of Soy Protein Isolate on the Characteristics and Structure: Function Relationship of Soluble and Insoluble Fractions." J. Agric. Food. Chem. 43 (9): 2471-9.

[8] Wagner, J. R., Sorgentini, D. A., and Añón, M. C. 1996. "Thermal and Electrophoretic Behavior, Hydrophobicity and Some Functional Properties of Acid-Treated Soy Isolates." J. Agric. Food. Chem. 44 (7): 1881-9.

[9] Panizzolo, L. A. 2005. "Protein Modification by an Enzymatic Way: Analysis of the Structure-Function Relation of the Hydrolysis Products." Ph.D. thesis, Chemistry School, Republic University, Montevideo, Uruguay, 80-130. (in Spanish)

[10] Petruccelli, S., and Añón, M. C. 1994. "Relationship between the Method of Obtention and the Structural and Functional Properties of Soy Protein Isolates: Part I, Structural and Hydration Properties." J. Agric. Food. Chem. 42 (10): 2161-9.

[11] Nagano, T., Hirotsuka, M., Kohyama, K., and Nishinari, K. 1992. "Dynamic Viscoelastic Study on the Gelation of 7S Globulin from Soybeans." J. Agric. Food. Chem. 40 (6): 941-4.

[12] Lowry, H., Rosebrough, N. J., Farr, A. L., and Randall, R. J. 1951. "Protein Measurement with the Folin-Phenol 
Reagent." J. Biol. Chem. 193 (1): 265-75.

[13] Hayakawa, S., and Nakai, S. 1985. "Relationships of Hydrophobicity and Net Charge to the Solubility of Milk and Soy Proteins." J. Food Sci. 50 (2): 486-91.

[14] Kato, A., and Nakai, S. 1980. "Hydrophobicity Determined by a Fluorescence Probe Method and Its Correlations with Surface Properties of Proteins." Biochim. Biophys. Acta 624 (1): 13-20.

[15] Deak, N. A., Murphy, P. A., and Johnson, L. A. 2007. "Characterization of Fractionated Soy Proteins Produced by a New Simplified Procedure." J. Am. Oil Chem. Soc. 84 (2): 137-49.

[16] Panizzolo, L. A., Mussio, L. E., and Añón, M. C. A. 2014. "A Kinetic Model for Describing the Effect of Proteins on the Air-Water Interface Tension." J. Food Sci. Eng. 4 (6): 282-90.

[17] Loisel, W., Guéguen, J., and Popineau, Y. A. 1993. "New Apparatus for Analyzing Foaming Properties of Proteins." In Food Proteins: Structure and Functionality, edited by Schwenke, K. D., and Mothes, R. Weinheim, Germany: VCH, 320-3.

[18] Panizzolo, L. A., Mussio, L. E., and Añón, M. C. A. 2012. "Kinetic Description for the Destabilization Process of Protein Foams." Inter. J. of Food Prop. 15 (1): 60-8.

[19] Wolf, W. J. 1993. "Sulfhydryl Content of Glycinin: Effect of Reducing Agents.” J. Agric. Food. Chem. 41 (2): 168-76.

[20] Petruccelli, S., and Añón, M. C. 1995. "Partial Reduction of Soy Protein Isolate Disulfide Bonds." J. Agric. Food. Chem. 43 (8): 2001-6.

[21] Hermansson, M. 1978. "Physico-Chemical Aspects of Soy Proteins Structure Formation.” J. Texture Stud. 9 (1-2): 33-58.

[22] Hermansson, M. 1986. "Soy Protein Gelation." J. Am. Oil Chem. Soc. 63 (5): 658-66.

[23] Wagner, J. R., and Añón, M. C. 1990. "Influence of Denaturation, Hydrophobicity and Sulfhydryl Content on Solubility and Water Absorbing Capacity of Soy Protein Isolate." J. Food Sci. 55 (3): 765-70.

[24] Puppo, M. C., and Añón, M. C. 1999. "Soybean Protein
Dispersions at Acid pH: Thermal and Rheological Properties." J. Food Sci. 64 (1): 50-6.

[25] Puppo, M. C. 1997. "Gelling Properties of Soy Proteins at Acidic pH." Ph.D. thesis, School of Exact Sciences, National University of La Plata, La Plata, Argentina, 27-36.

[26] Abirached, C., Medrano, C. A., Panizzolo, L. A., Moyna, P., and Añón, M. C. 2010. "Stability of Foams Made with Soy Protein Treated with Acid pH.” INNOTEC 5: 58-62. (in Spanish)

[27] Martin, H., Bos, M. A., and Van Vliet, T. 2002. "Interfacial Rheological Properties and Conformational Aspects of Soy Glycinin at the Air-Water Interface." Food Hydrocolloids 16 (1): 63-71.

[28] Stubenrauch, C., and Miller, R. 2004. "Stability of Foam Films and Surface Rheology: An Oscillating Bubble Study at Low Frequencies.” J. Phys. Chem. B 108 (20): 6412-21.

[29] Koelsch, P., and Motschmann, H. 2005. "Relating Foam Lamella Stability and Surface Dilational Rheology." Langmuir 21 (14): 6265-9.

[30] Benjamins, J., Cagna, A., and Lucassen-Reynders, E. H. 1996. "Viscoelastic Properties of Triacylglycerol/Water Interfaces Covered with Proteins." Colloids Surf. A 114 (20): 245-54.

[31] Freer, E., Yin, K., Fuller, G., and Radke, C. 2004. "Interfacial Rheology of Globular and Flexible Proteins at the Hexadecane/Water Interface: Comparison of Shear and Dilatation Deformation Surface Dilational Modulus or Gibbs' Elasticity of Protein Adsorption Layers." $J$. Phys. Chem. B 108 (12): 3835-44.

[32] Yu, M. A., and Damoradan, S. 1991. "Kinetics of Destabilization of Soy Protein Foams." J. Agric. Food Chem. 39 (9): 1563-7.

[33] Salager, J. L., Andérez, J. M., and Forgiarini, A. 2003. "Influence of Formulation on Foams." Cuaderno Firp 263-A, University of Los Andes, Mérida, Venezuela. Accessed June 12, 2004. http://www.firp.ula.ve/archivos/cuadernos/S263A.pdf. (in Spanish) 